\title{
Zeppelin-basen i Tønder 1915-1918
}

\section{Strategisk baggrund og taktisk betydning}

\section{Af Dennis Christian LaRsen}

I begyndelsen af 1915 blev der anlagt en stor luftskibsbase lidt nord for Tønder. I sommeren 1918 gennemførte britiske fly et luftangreb, der ødelagde basen. Angrebet var den eneste direkte krigshandling på sønderjysk jord. Stud.mag. Dennis Christian Larsen undersøger her baggrunden for anlæggelsen af basen og dens krigsmæssige betydning for den kejserlige tyske marine i perioden 1915-1918.

Den 19. juli 1918 blev luftskibsbasen nord for Tønder angrebet af engelske fly. Basen bestod på dette tidspunkt af en stor dobbelt hangar, Toska, med de to zeppelinere L54 og L60, samt en mindre hangar, Tobias, med en såkaldt lænkeballon. Derudover bestod basen af lysfyr, benzinlagre, barakker, radiostation, gasværk, flyhangar og andre installationer. Det britiske luftangreb på basen i Tønder blev foretaget fra historiens første anvendelige hangarskib, H.M.S. Furious, der var udstyret med syv fly af typen Sopwith Camel. Basen blev overrasket klokken 04.32 af en gruppe på tre fly, og ca. fem minutter senere angreb yderligere tre. Angrebet var en succes for englænderne. Basen mistede de to zeppelinere $L 54$ og $L 60$ og fik ødelagt sin lænkeballon. ${ }^{1}$

\section{Taktik og strategi}

Marine-Luftschiff-Detachement Tonderns betydning skal ses i lyset af de taktiske og strategiske overvejelser, som chefen for den tyske admiralstab, admiral Alfred von Tirpitz, og den tyske Hochseeflotte gjorde sig for krigen. Tirpitz regnede med en tæt blokade af Tyskland med udgangspunkt i Tyske Bugt. Ved en sådan tæt blokade kunne den britiske Grand Fleet udsulte den tyske befolkning og på denne måde ødelægge landets industri og infrastruktur. Den tyske admiralstab udviklede derfor sin strategi ud fra denne forventning. ${ }^{2}$ 
Den tyske strategi tog udgangspunkt $i$, at den tyske Hochseeflotte ved krigens udbrud var den engelske Grand Fleet underlegen i antal Dreadnoughts (slagskibe) i forholdet $23 \mathrm{mod} 32 .{ }^{3}$ Desuden var den engelske flådes tilvækst $\mathrm{i}$ nybyggede skibe den tyske marines langt overlegen. Hvor den kejserlige tyske flådes tilvækst af linieskibe var to nybygninger efter 1914, var Grand Fleets tilvækst elleve nybyggede skibe. ${ }^{4}$ Den tyske Hochseeflottes plan var at svække den engelske flåde gennem nålestiksoperationer i kystnære områder. Kystbatterier, ubåde, motortorpedobåde og miner skulle langsomt udligne den engelske flådes overlegenhed, måske endda skaffe Hochseeflotte en fordel i antallet af skibe. Forst derefter skulle det endelige slag stå.

Uheldigvis for den tyske admiralstab udeblev den engelske tætte blokade, da krigen kom. Englænderne havde allerede i 1912 opgivet denne taktik. Admiral Jellicoe, den øverstbefalende for Grand Fleet, havde vurderet den tætte blokade ud fra de seneste moderne våbenudviklinger og forkastet ideen som for farlig: Den stadige udvikling af miner og torpedoer umuliggjorde en tæt overvågning af Helgolandsbugten med tunge skibe, mente han. ${ }^{5}$ Jellicoes analyse var altså sammenfaldende med Tirpitz'. Jellicoe og hans stab introducerede i stedet en fjernblokade, hvor den sydlige blokadelinje spærrede den Engelske Kanal omkring Doverstrædet og den nordlige blokadelinje spærrede strædet mellem Skotland og Norge. ${ }^{6}$

Den tyske flåde måtte følgelig udvikle en ny strategi. Admiral von Ingenohls ordre fra den 14. august 1914 udtrykker klart den nye tyske strategi: »Vor umiddelbare opgave er derfor at forårsage fjendtlige tab ved hjælp af enhver tænkelig form for guerrilla-krig, hvor som helst vi kan finde ham. Denne opgave vil primært hvile på vore lette styrker. (...) Den pligt, der i mellemtiden påhviler slagskibsflåden, er at holde dette, vort hovedvåben, skarpt og skinnende, indtil den dag, da vi skal udkæmpe det afgørende slag. « Admiralstaben underbyggede desuden flådens guerilla-strategi med flere krigsnyttige argumenter, bl.a. frigørelse af tropper til hæren, og muligheden for at opretholde handelsøkonomisk pres på de neutrale lande. ${ }^{7}$ Sammenfattende kan Hochseeflottes vigtigste opgaver på dette tidspunkt beskrives som:

1. At holde Hochseeflotte intakt og dermed udøve pres på Grand Fleet og de neutrale lande.

2. At forsøge at svække den engelske flåde og kun indlade sig på kamp under favorable betingelser og ved numerisk overlegenhed. 


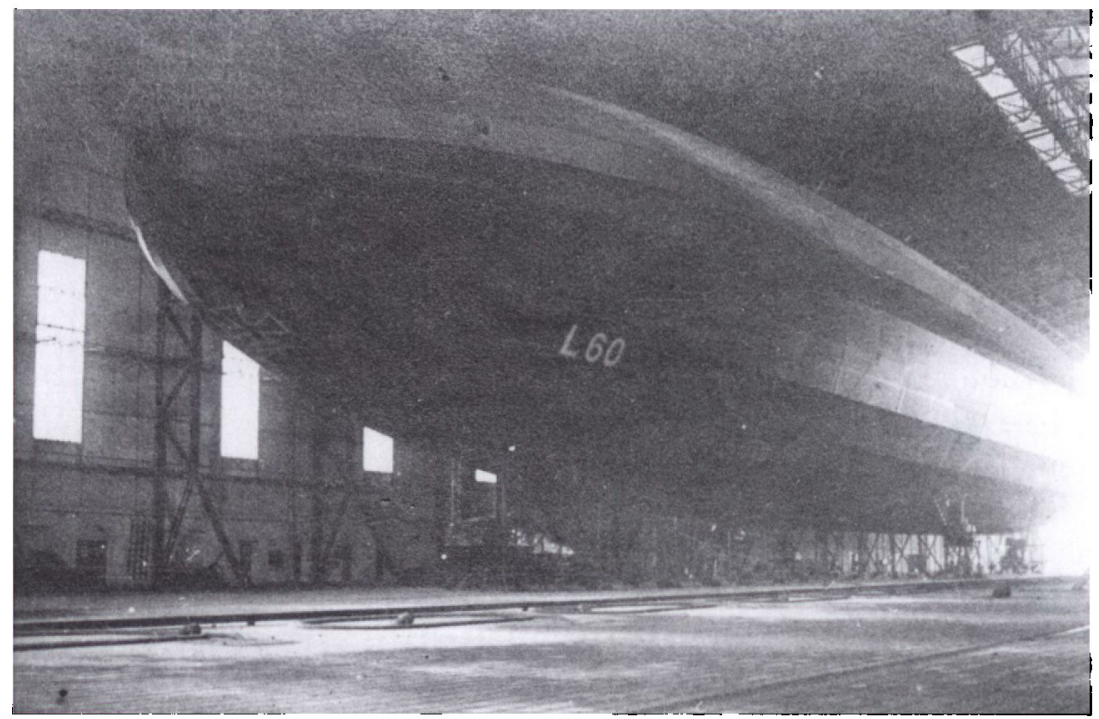

Zeppelineren L60 delte dobbelthangaren med "Toska« søsterskibet L54. L60 var 195,5 meter lang - mere end dobbelt sả lang som en fodboldbane. Den havde en diameter på 23,9 meter på det bredeste sted. Dens tophastighed var $160,5 \mathrm{~km} / \mathrm{t}$, dens rækkevidde var på $13.500 \mathrm{~km}$ og dens maksimale flyvehojde 5.400 meter. L60 blev taget i brug den 18. december 1917 og nåede at flyve elleve rekognosceringstogter og ét bombeangreb, for den sammen med L54 gik op i flammer under det britiske angreb i sommeren 1918. Foto: Zeppelin-Museet, Tonder.

Den nye strategi medførte, at den underlegne Hochseeflotte nu var nødt til at opsøge fjenden. Derved blev der lagt yderligere pres på de tyske flådestyrker, og flåden blev derfor nødt til at prioritere rekognoscering højere for at undgå tab. Men bedre rekognoscering krævede flere store skibe - og dem havde man hverken tid eller råd til at anskaffe sig. Pris og produktionshastighed fik derfor vital betydning for den tyske marinestrategi og -taktik. Der måtte følgelig tænkes nyt, og luftskibene synes at være svaret på både nytænkning og behov. Det tog nemlig kun seks uger at bygge et zeppelin-luftskib mod ca. to år for et slagskib. ${ }^{8}$ Et luftskib af typen L3 kostede i 1914 desuden 1.000 .000 rigsmark, mens en let slagkrydser kostede 8.800 .000 rigsmark og en tung slagkrydser hele 59.000 .000 rigsmark. Luftskibe af typen zeppelin, der skulle blive flådens foretrukne, blev derfor løsningen på det problem, den tyske flåde stod over for, da 1. Verdenskrig brød ud. Halvanden måned efter krigsudbruddet, den 16. september 
1914, besluttede flådeledelsen at anlægge tre luftskibsbaser: I Hage, Namur og Tønder. 9

Marine-Luftschiff-Detachement Tondern blev den tyske flådes nordligst beliggende luftskibsbase. Basen i Tønder var tættest på størsteparten af den engelske hjemmeflåde, som lå stationeret i Scapa Flow på Orkney-øerne nord for Skotland. Tønder-basens beliggenhed var et bevidst valg - og viser dens vigtighed som modvægt til den engelske fjernblokade. Basen skulle rekognoscere i den nordlige del af Nordsøen og Skagerrak samt være værn mod eventuelle ubehagelige overraskelser fra Grand Fleet. Marine-Luftschiff-Detachement Tondern trådte ifølge krigsdagbøgerne den 4. maj 1915 operativt ind i krigen.

Straks fra anlæggelsen var Tønder-basen særdeles vigtig for den tyske flåde, både ud fra den nye tyske strategi, ud fra militærets og flådens vurdering af luftskibet som våben og ud fra nøgterne behovsanalyser. Både Centralmagterne og Ententen vurderede i denne fase af krigen luftskibenes muligheder meget højt - og meget ens. ${ }^{10}$ Også briterne anså Tønder-basen for at have stor krigsmæssig betydning, hvad der også bekræftes af Grand Fleets forskellige angrebsforsøg.

\section{Rekognoscering}

I tidsrummet 1906-1911 undersøgte den tyske marine luftskibenes anvendelsesmuligheder. Undersøgelserne viste, at luftskibe i en højde på 500 meter havde et sigt på ca. 47 sømil. ${ }^{11}$ Det gjorde dem særligt velegnede til rekognoscering, minesøgning, og eskorteflyvning for flådens skibe, hvilket også endte med at blive marineluftskibenes militære hovedformål. ${ }^{12}$

Briterne nåede samme konklusion. I 1912 deltog to engelske teknikere $\mathrm{i}$ en flyvning ombord på det tyske luftskib Viktoria Luise. I rapporten til det engelske forsvarsministerium hedder det: »De tyske luftskibe kan i klart vejr allerede nu sættes på rekognoscering over store områder af Nordsøen, og ét eneste luftskib kan, takket være sit overblik fra stor højde under favorable vejrbetingelser, udføre de samme rekognosceringsopgaver som adskillige opklaringskrydsere. Det er vanskeligt at overvurdere værdien af denne fordel for Tyskland. Ved systematisk og regelmæssig patruljering af kysten vil det $i$ godt vejr være muligt for tyske luftskibe at opdage enhver fjende, der nærmer sig, og give rettidig advarsel om angrebet ${ }^{13}{ }^{13}$ Briterne 
forandrede som næunt deres blokadestrategi som følge af dette nye våben.

Tønder-basens vigtigste funktion var netop rekognoscering. Den tyske flåde fløj med alle sine 76 operative marineluftskibe $i$ alt 1.191 rekognosceringstogter fra sine $\mathrm{i}$ alt 15 luftskibsbaser. Af disse 1.191 rekognosceringstogter var de 277 fra Marine-Luftschiff-Detachement Tondern. Det viser en gennemgang af de tyske krigsdagbøger for basen. Det vil sige, at Tønder-basens zeppelinere fløj $23 \%$ af det samlede antal tyske rekognosceringsmissioner. ${ }^{14}$

Det første operative togt med rekognoscering som formål fandt sted den 4. maj 1915 og det sidste den 16. juli 1918. Basen var operativ i 1.174 af de $i$ alt 1.586 dage, krigen varede. ${ }^{15}$ I betragtning af, at Tønder-basen var operativ i kortere tid end mange andre baser, der var anlagt før krigen, så forstærker de $23 \%$ billedet af rekognoscering som basens hovedopgave.

Antallet af rekognosceringsmissioner fra Marine-Luftschiff-Detachement Tondern toppede i 1916, for derefter at dale. Dette indikerer luftskibenes store betydning for marinen frem til 1917, hvilket også Tønder-basens store andel af det samlede antal rekognosceringsmissioner synes at afspejle. Dog afslører tallene også en ganske stor ineffektivitet. Basen var f.eks. ikke i stand til at flyve i 896 dage ud af de 1.174 dage, den var operativ! De kæmpemæssige luftskibe var navnlig sårbare over for vejr- og vindforhold.

Tønder-basens krigsmæssige betydning bør bedømmes ud fra to perioder. Den første periode fra oprettelsen af basen til januar 1917. $\mathrm{Og}$ anden periode fra januar 1917 til basens operative ophør 19. juli 1918. ${ }^{16}$ Den første periode var præget af den kejserlige tyske marines taktiske og strategiske overvejelser og Jyllandsslaget. I den anden periode blev presset på England opretholdt via angrebsflyvning og rekognoscering, men afslørede samtidig luftskibenes sårbarhed og ineffektivitet.

\section{Jyllandsslaget}

Jyllandsslaget den 31. maj til 1. juni 1916 var en følge af ændringen i den tyske strategi og den tyske Hochseeflottes forsøg på at omsætte den i praksis. Den tyske flådes første forsøg blev iværksat den 25. april 1916. Det var en nålestiksoperation mod havnene Lowestoft og Yarmouth ved den engelske nordsøkyst. Angrebene på de to kystbyer 

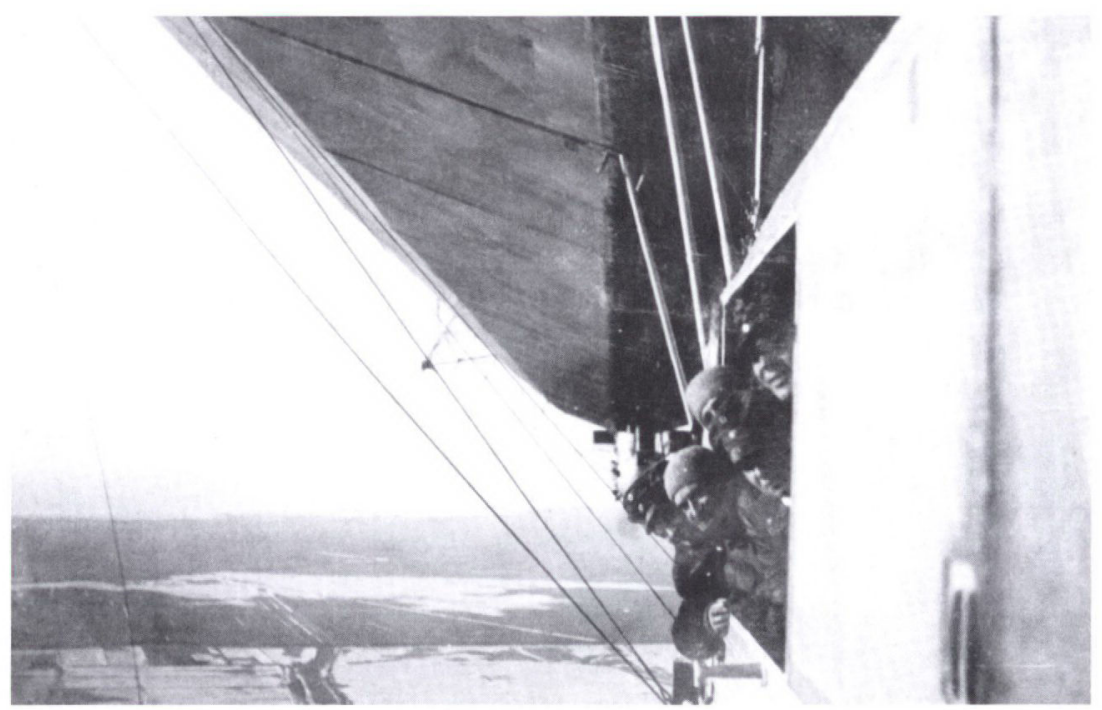

Rekognoscering var den vigtigste opgave for de luftskibe, der var stationeret på basen $i$ Tonder. Luftskibe $i$ en højde af 500 meter havde under gunstige forhold et sigt pa ca. 47 somil. Opfindelsen af zeppelineren forte til en grundlaggende forandring af søkrigsstrategien. Foto: Zeppelin-Museet, Tonder.

skulle føre til en deling af Grand Fleet, hvorved den tyske flåde ville opnå overlegenhed over for den ene halvdel. ${ }^{17}$ Fra basen i Tønder deltog luftskibet 27 . Operationen mislykkedes dog og forandrede ikke situationen. ${ }^{18}$ Den tyske admiralstab lagde en ny koordineret plan for et angreb på kystbyen Sunderland længere mod nord og med samme formål. Både ubåde og zeppelinere skulle deltage $\mathrm{i}$ angrebet. ${ }^{19}$ På grund af dårligt vejr i dagene fra den 23. maj og frem til den 30 . maj var luftskibene dog ikke i stand til at rekognoscere. ${ }^{20}$ Den tyske flåde opgav at vente på bedre vejr og satte den ene af to alternative planer i gang. Operationsplanen blev ændret fra et angreb på den engelske kyst til et angreb på engelske handelsskibe og krydsere i Skagerrak. ${ }^{21}$ Admiral Reinhard Scheer gav ordren med begrundelsen: "Luftrekognoscering var her ganske vist onskværdig, men ikke absolut nødvendig «. ${ }^{22}$

Den tyske admiralstab anså på dette tidspunkt (1916) luftskibsrekognoscering for at være nødvendig forud for de fleste beslutninger i forhold til den engelske flåde. Det var fortsat luftskibene, der skulle give den tyske flåde den taktiske fordel. I det nævnte eksempel dog på den indirekte måde, at det var luftskibenes p.g.a. vejrforholdene 
manglende evne til at rekognoscere, som forandrede planerne - og dermed førte til Jyllandsslaget.

Jyllandsslaget mellem Grand Fleet og Hochseeflotte er det største søslag $i$ verdenshistorien. I slaget deltog $i$ alt 250 skibe med en bemanding på i alt ca. 90.000 mand. England havde - igennem efterretninger - fået forhåndskendskab til de tyske planer og havde derfor truffet sine forholdsregler. Slaget mellem de to flåder kulminerede ca. kl. 15.30 den 31. maj 1916 i en kraftig artilleriduel, som resulterede i betydelige tab på begge sider. England mistede fjorten skibe og 6.274 mand, og de tyske tab var på elleve skibe og 2.545 mand. På trods af Grand Fleets relativt større tab, blev den tyske Hochseeflotte alligevel trængt i defensiven og slaget endte i et tysk, strategisk nederlag. Reinhard Scheer besluttede ikke at sætte resten af den kejserlige flåde på spil, og slog sig i løbet af natten igennem mod Wilhelmshafen.

Jyllandsslaget forrykkede ikke styrkeforholdet og magtbalancen på havet. Begge parter påberåbte sig en sejr. England beherskede fortsat havet og havde den 2 . juni 32 slagskibe og krydsere klar, hvorimod Tyskland først atter kunne stå til søs $i$ august. ${ }^{23}$ Tyskerne hævdede derimod, at Hochseeflotte havde vundet en strategisk sejr ud fra beregningen af sænket tonnage. Grand Fleet havde sænket 62.000 tons, hvor Hochseeflotte havde sænket 110.000 tons. ${ }^{24}$

Luftskibene havde overhovedet ingen indflydelse på Jyllandsslaget. Der blev ganske vist sendt fem luftskibe op i løbet af eftermiddagen den 31. maj, men ingen af dem så noget til slaget. ${ }^{25}$ Det skyldtes i første omgang vejret, der gjorde det umuligt at lette, og da luftskibene endelig kom i luften, var afstanden til slaget for stor. Vejret beskrives i krigsdagbogen for Tønder-basen den 31. maj 1916 som: »Vorm: Trüb, diesig, böige nordwestliche Winde. Nachm: Etwas aufklarend aber noch überwiegend bedeckt, mäßige westliche Winde". L21 beskrev fra sin position i Nordsøen vejret som tåget med lavtliggende skydække og en sigtbarhed på tre-ti sømil. ${ }^{26}$ Mens første gruppe af luftskibe returnerede til deres baser uden informationer, steg en ny gruppe på seks luftskibe op for at rekognoscere på de af admiralstaben beordrede positioner. ${ }^{27}$ Fra Marine-Luftschiff-Detachement Tondern deltog $L 24$ og $L 22$ med opstigning klokken 00:10 den 1. juni. ${ }^{28}$ Jyllandsslaget blev afsluttet fra tysk side klokken 7:26 den 1. juni 1916, da det meddeltes, at det ikke længere var nødvendigt med rekognoscering.

Det var ikke meningen, at luftskibene skulle spille nogen rolle $\mathrm{i}$ forbindelse med Jyllandsslaget. Scheer havde netop iværksat en alter- 
at eit Blity die 27ad?t durcḩ̧ưft?

Z̈lngiflich dưft die berde -

$\mathfrak{D b}$ der Eimmel feuer ipuft

ziieder auf die Erde?

Fier und dort madht facon ein Brand

Stadt und felder heller -

luber dem eridireften zand

Surren die propeller.

2lus den engen (5afien quillt

Dampi in grauen Wellen,

Unt die 2llörier fdpiegen wild

Don den ङ̄itadellen.

Wie durdt's Waijer ein Delphin,

(j)ieht in hoher ferne

lhweriehrt ein Eeppelin

Leinuärts ourd? oie Sterne.

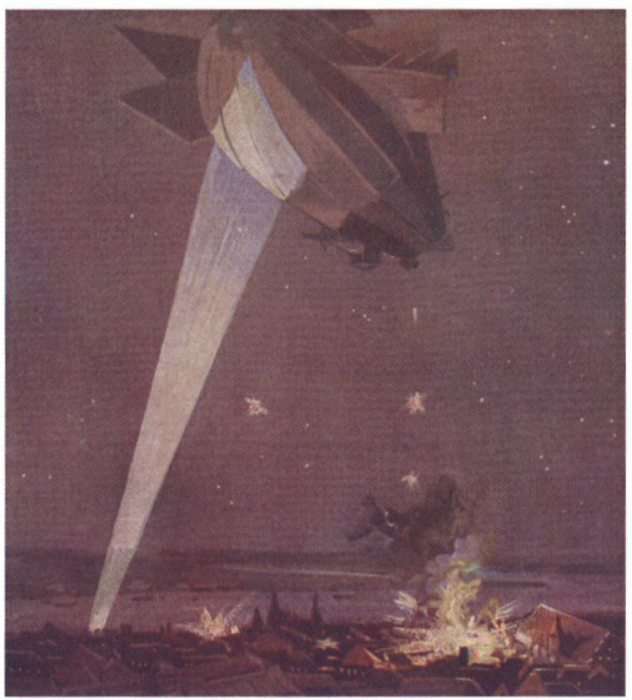

Zeppelinerne blev for forste gang brugt til strategisk bombuing af mål $i$ England $i$ januar 1915. Den rædsel, angrebene spredte, var dog storre end de materielle gdelaggelser. Bombningerne satte et teknologisk luftkapløb i gang: Zcppelinerne var nemlig pga. deres store flywehojde uden for rækkevidde af britiske jagerfly. Og selvom flyzemaskinernes flyvehojde blev stadigt forbedret, sấ skete dor en tilsvarende udvikling med zeppelinerne. I denne tyske bornebog fra 1. Verdenskrig hedder det $i$ slutningen af verset, at zeppelineren uskadt kan drage hjem igen efter endt bombetogt. Det var just dette, der forte til en britisk beslutning on $i$ stedet at odelagge luftskibene på deres baser. Fra: bornebogen "Vater ist im Kriege", udgivet af Kriegskinderspende deutscher Frauen.

nativ plan, fordi det ikke var muligt at rekognoscere med luftskibe. Men den øverstbefalende for den tyske Hochseeflotte bibeholdt sin overbevisning om, at rekognoscering stadigvæk var vital for den tyske marine, både for at undgå overraskelser under fremtidige operationer og for at modvirke den engelske flådes numeriske overlegenhed. ${ }^{29}$

Havde luftskibene kun ringe betydning for Jyllandsslaget, så havde Jyllandsslaget så meget desto større betydning for luftskibene - i hvert fald for luftskibsbasen i Tønder. I månederne efter Jyllandsslaget - juli, august og september 1916 - skete der en markant forøgelse af flyvningerne. Det fremgår af Tønder-basens krigsdagbog, at der i de tre sommermåneder blev fløjet $\mathrm{i}$ alt 62 rekognosceringsmissioner, svarende til $46 \%$ af samtlige rekognosceringsmissioner for året 1916. Året 1916 var i det hele taget det år, hvor Marine-Luftschiff-Detache- 


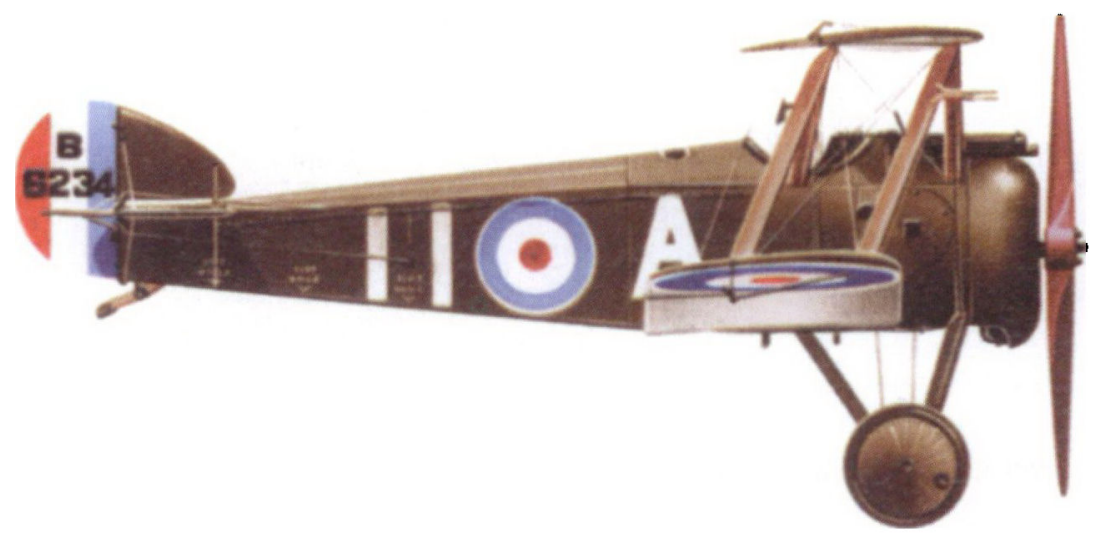

Det var britiske jagerfly af typen Sopwith Camel, der gennemfarte angrebet mod zeppelin-basen $i$ Tonder. Flyet blev taget $i$ brug $i$ sommeren 1917 og var pa dette tidspunkt den mest avancerede britiske jager. Sopwith Camel er krediteret for 1.294 nedskydninger af fjendtlige fly - flere end nogen anden allieret jager. Men allerede efter ét dirs tjeneste var den blevet overhalet af nye flytyper, og den blev herefter navnlig brugt til bombeangreb og infanteristøtte. Fra: Williamson Murray: Krigen $i$ luften 1914-1945, Kobenhavn 2001, s. 57.

ment Tondern var mest operativ under hele krigen. Det gjaldt både for antallet af rekognosceringsmissioner og for basens deltagelse $\mathrm{i}$ angrebsflyvninger.

En af forklaringerne på den markante stigning $\mathrm{i}$ antallet af operationer var, at den tyske Hochseeflotte i perioden juni-oktober 1916 havde ni skibe til reparation i tørdok. ${ }^{30}$ Der skulle kompenseres for de manglende skibe, og den tyske marines eneste mulighed var en intensiveret brug af luftskibe. Basen i Tønders strategiske beliggenhed har formentlig også betydet, at det blev den, som kom til at stå for hovedparten af den tyske flådes rekognoscering over Nordsøen.

\section{Angrebsflyvning}

Angrebsflyvningen var en betydningsfuld del af det samlede trusselsbillede, som herskede i England under hele krigen. De samlede tab af menneskeliv og den materielle skade beløb sig ifølge nutidige beregninger til ca. 550 mennesker og ca. 1.500 .000 engelske pund. De relativt små tab skal sættes $i$ forhold til, at angriberne mistede $40 \%$ af alle luftskibe. ${ }^{31}$ Trods gode efterretninger var briterne ikke i stand 
til at vurdere de forskellige basers specifikke mål og opgaver. ${ }^{32}$ For England var alle tyske luftskibsbaser derfor lige farlige.

Også angrebsflyvningerne kulminerede for Tønder-basen i 1916. Admiral Scheer mente ved hjælp af luftskibene at kunne tvinge England ud af krigen gennem strategisk bombning af landets infrastruktur. Det gengives specifikt $i$ en ordre fra den 10. august 1916. Men for basen i Tønder var angrebsflyvning kun af minimal betydning. ${ }^{33}$ Luftskibe fra Marine-Luftschiff-Detachement Tonderns fløj blot $25 \mathrm{ud}$ af de i alt 352 bombemissioner udført af alle luftskibe i 1. Verdenskrig. Det svarer til blot $7 \% .^{34}$

Den tyske hærs luftskibe blev første gang brugt til at angreb allerede den 6 . august 1914, nemlig mod fæstningsværkerne i den belgiske by Liège og byens industri. Den tyske marines luftskibe deltog første gang i en strategisk bombning i dagene fra den 19. januar 1915 til 20. januar 1915 mod udvalgte mål i England. ${ }^{35}$

Når den tyske flådes luftskibe begyndte på strategisk bombning (og dermed inddragelsen af civilbefolkningen i krigen), havde det flere årsager. Først og fremmest skyldtes det den tyske militære ledelses forsøg på at tvinge England ud af krigen ved hjælp af strategisk bombning af militære mål og nedbrydning af den engelske befolknings moral. ${ }^{36}$ Sekundært ønskede man at binde så stort et antal tropper og materiel til forsvar af England som muligt for derved at svække den britiske front på det europæiske kontinent. Ved udgangen af 1916 blev der således i England tilbageholdt ca. 18.000 mand, 110 fly og et stort antal antiluftskyts og lyskastere til forsvar mod luftangreb. ${ }^{37}$

Endelig indeholdt bombningerne et element af hævn. Den 4 . december og den 19. december 1914 angreb franske fly nemlig Freiburg med svære civile tab til følge, hvilket førte til et udbredt ønske om gengældelse i den tyske befolkning. Kejser Wilhelm II var tilbageholdende med at godkende den strategiske bombning på grund af sit nære familieforhold til det engelske kongehus, men den 12 . februar 1915 gav han endelig ordre til angreb. ${ }^{38}$ Fra dette tidspunkt og indtil juni 1917 var angrebsflyvning mod England en del af den tyske hærs luftskibes operative opgaver. ${ }^{39}$ For den tyske marine sluttede angrebsflyvningen først den 5 . august 1918 med nedskydningen af luftskibet $L 70$. Ombord var føreren af marineluftskibsafdelingen Peter Strasser. ${ }^{40}$ 


\section{Teknologisk udvikling}

Da luftangrebene begyndte, fandtes der intet brugbart forsvar. Flyvningen var endnu helt på det eksperimentelle stadium, da krigen startede. Fly blev mest brugt til rekognoscering og medførte kun de eventuelle håndvåben, piloten selv tog med. Flyvemaskinen udgjorde derfor ved krigens begyndelse ingen trussel mod luftskibene. ${ }^{41}$ Den statiske flyvehøjde for et luftskib af typen "m " var 2.000 meter; en højde, som den første model af flytypen Bristol B.E.2A slet ikke havde mulighed for at nå. ${ }^{42}$ Men den teknologiske udvikling gik stærkt, og modellen Bristol B.E.2C kunne i 1916 nå en højde på 3.352,80 meter og var nu blevet udstyret med et kaliber 303 maskingevær af mærket Lewis.

Også inden for antiluftskyts gik udviklingen stærkt. I begyndelsen var antiluftskytset til størst fare for civilbefolkningen og aldeles harmløs for luftskibene. Det ændrede sig med opfindelsen af fragmentationsgranaten, der var særdeles farlig for luftskibene. ${ }^{43}$ Den kontinuerlige udvikling af de engelske fly, våben etc. forte til udviklingen af marineluftskibene type $s, t, u, v, w o g x$ med en stadigt stigende statisk flyvehøjde fra 5.029,20 meter til 6.400,80 meter. Det gjaldt for luftskibene først og fremmest om at komme uden for flyvemaskinernes rækkevidde.

En ny type luftskibe blev sat ind den 28 . februar 1917, og denne gang vedblev luftskibene at være uden for de britiske flys rækkevidde helt indtil slutningen af krigen, da engelske Bristol og Avro fly endelig opnåede samme flyvehøjde. ${ }^{44}$ De krigsførende parter både agerede og reagerede på de krigsmæssige udfordringer. Men den tyske marine var med sine luftskibe og innovationer i stand til at opretholde presset på det engelske forsvar under hele krigen.

Med de nye zeppelintyper opstod nye problemer. Zeppelinernes største problem var opdriften. Det var et fælles træk hos alle de tyske luftskibe gennem hele krigen. Opdriften blev leveret af brint. Brintens største problem var, at den var meget let antændelig. Men den lod sig ikke udskifte med f.eks. helium, som kun fandtes i USA. Dette var luftskibets akilleshæl gennem hele krigen.

Et stort problem med de nye, højtflyvende zeppelinere var kulde og højdesyge. De lave temperaturer førte ofte til forfrysninger, ${ }^{45}$ og i mere end 4.000 meters højde begyndte højdesyge at påvirke besætningen. ${ }^{46}$ Højdesyge medførte hovedpine, kvalme, åndenød, ekstrem 


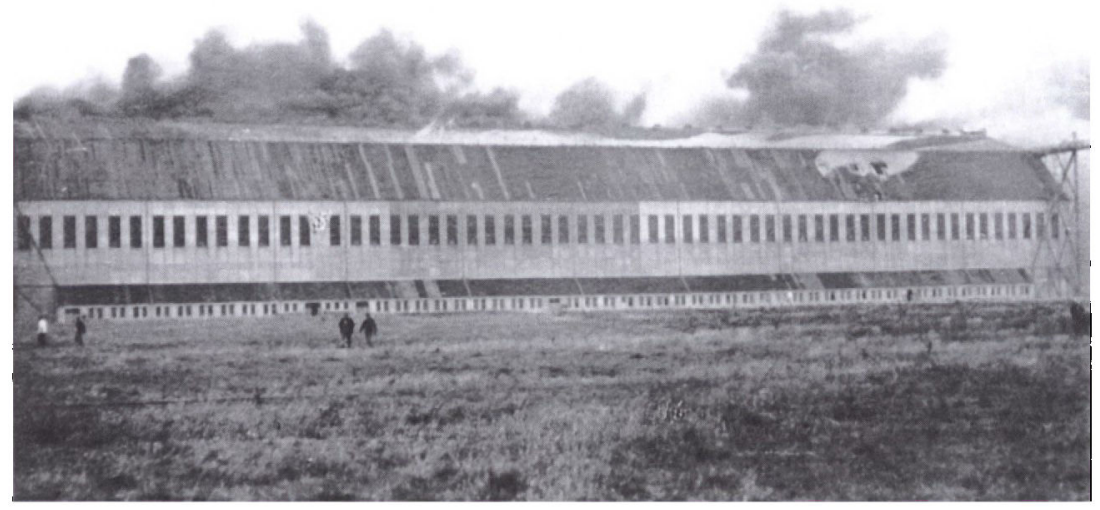

Den 19. juli 1918 tidligt om morgenen blev zeppelin-basen ved Tonder overrasket af to angrebsbolger med hoer tre britiske fly. De var lettet fra H.M.S. Furious - det forste anvendelige hangarskib $i$ verden. Flyene flaj ind over land nord for Tonder og fulgte jernbanelinjen sydpå til zeppelin-basen. Det var nærmest umuligt ikke at ramme den kolossale luftskibshangar "Toska" med sit indhold af zeppelinere, der straks brod $i$ brand. Foto: Zeppelin-Museet, Tønder.

træthed, næseblod, besvimelse - og i nogle tilfælde døden. Primitive iltapparater blev udviklet til brug på luftskibene. Men beregninger viste, at 120 meters gang i et luftskib med iltapparat tog ca. 40 minutter, hvilket antyder, at ulemperne ved iltapparaterne var større end fordelene. ${ }^{47}$ Vejret var i de nye højder desuden anderledes ekstremt for et luftfartøj lettere end luft. ${ }^{48}$ Da luftskibets præstation blev påvirket af selv små vejrmæssige udsving i temperatur, skydække, sigtbarhed og vind, og da datidens meteorologer ikke kunne give en prognose $\mathrm{i}$ denne højde, blev både vejret og den manglende vejrudsigt et stort problem. ${ }^{49}$ Selv $\mathbf{i}$ dag gælder de vejrudsigter, som luftfarten arbejder med, kun i to timer. Dårligt vejr $\mathrm{i}$ stor højde førte til fejlnavigering, afdrift, fejlbombning etc. ${ }^{50}$

Den 25. maj 1917 bombede tyske flyvemaskiner for første gang England. Kejser Wilhelm II sammenlignede flyangrebet med luftskibsangrebet natten for og konkluderede: "Jeg er på trods af succes'en af den mening, at tiden med angreb på England fra luftskibe nu er forbi. Luftskibene skal herefter bruges til opklaringsopgaver for 
Højsøflåden og til strategisk fjernrekognoscering, men ikke til bombeangreb på England «. ${ }^{51}$ Den 16. juni 1917 angreb L42 og L48 England. Den ene af de to højtflyvende zeppelinere, $L 48$, blev på grund af en fejl skudt ned. Dette foranledigede foreren for marineluftskibene til endnu engang at bekræfte luftskibenes vigtighed overfor den øverstbefalende for marinen Reinhard Scheer og betone nødvendigheden af at opretholde presset på England med fortsatte angreb. ${ }^{52}$

Et af de sidste større bombeangreb med luftskibe fandt sted den 19. oktober 1917. Elleve marineluftskibe deltog, herunder $L 45$ og $L 54$ fra Tønder. ${ }^{53}$ Angrebshøjden for luftskibene var på grund af det engelske forsvar på dette tidspunkt ca. 6.000 meter. Men i denne højde blev luftskibene fanget $i$ en storm med vindhastigheder på op til 110 $\mathrm{km} / \mathrm{t}$. Fem af de elleve marineluftskibe gik tabt, inklusive $L 45$ fra basen i Tønder. ${ }^{54}$ Den tyske luftskibsledelse bedømte ikke angrebet som nogen absolut katastrofe, men beskyldningerne føg, og meteorologerne endte med at få skylden.

I England blev angrebet derimod bedømt helt anderledes - og bekymrende! Man kaldte det "The Silent Raid" (»Det tavse angreb«), fordi det ikke havde været muligt på jorden at høre lyden af luftskibenes motorer i den store højde og antiluftskytskanonerne derfor forblev tavse. Ikke færre end 73 flyvemaskiner var blevet sendt op for at imødegå angrebet, men ingen af dem var i stand til at nå zeppelinernes flyvehøjde. Den daværende chef for luftforsvaret beskrev truslen således: »Af alle de angreb, jeg har oplevet, var dette langt det farligste og samtidig uden tvivl det vanskeligste at imødegå." Angrebet viste, at fjenden var i stand til at placere sin luftskibsflåde over London og kaste sine bomber - og at briterne intet kunne gøre for at forhindre det. Selvom angrebet ikke kostede menneskeliv eller nævneværdig materiel ødelæggelse, så måtte briterne konstatere, at luftskibene kom og gik uhindret, og at truslen fra luften igen var blevet meget realistisk. $^{55}$

For Marine-Luftschiff-Detachement Tondern udgjorde angrebsflyvningerne kun en meget lille del af de operative opgaver. Men basen var fuldt operativ og i stand til at deltage i alle krigsmæssige opgaver. Basen bidrog dermed til presset på England. Og derfor var den et oplagt mål for et britisk angreb. 


\section{Luftangrebet på Tønder-basen}

Den britiske marineminister, Winston Churchill, besluttede allerede i 1914, at eftersom hjemmeforsvaret var ineffektivt, så måtte zeppelinerne angribes på deres baser. ${ }^{56}$ De første angreb fandt sted allerede få måneder inde i krigen, nemlig i Düsseldorf og Köln den 22. september 1914. Angrebet mislykkedes første gang, men blev gentaget med succes den 8. oktober 1914, da en zeppelin i Düsseldorf blev ødelagt. Flere gange i lobet af krigen blev zeppelin-baser angrebet. Basen i Friedrichshafen blev ramt den 21. november 1914 med et ødelagt gasanlæg og en ødelagt zeppelin til følge, og desuden blev basen i Cuxhaven forsøgt angrebet den 25. december 1914. Briternes mål var at ødelægge luftskibene på deres baser, og dette mål blev forfulgt gennem hele krigen. ${ }^{57}$ Basen i Tønder blev forsøgt angrebet både den 25. marts 1916 og den 4. maj 1916, før det endelig den 19. juli 1918 lykkedes at få ram på den. ${ }^{58}$

Den angribende engelske flådestyrke omfattede ca. seksten destroyere, seks lette krydsere, fire slagskibe samt hangarskibet Furious. Desuden indgik der ubåde samt eksterne flådestyrker til at lægge minebælter som værn mod et eventuelt tysk angreb. Antallet af engelske flådefartøjer var et udtryk for den høje prioritet, som angrebet på Marine-Luftschiff-Detachement Tondern fik hos den øverste militære ledelse. Det var tillige et udtryk for en stor risikovillighed i betragtning af risikoen for at flådestyrken kunne blive opdaget af den tyske flåde, af flyvemaskiner - eller af luftskibe!

Angrebet var planlagt til den 18. juli 1918, men kunne ved dårligt vejr eller andre problemer udskydes 24 timer. Dette blev også slutresultatet. ${ }^{59}$ Ved en forlængelse af tidsfristen var risikoen for opdagelse større - og dermed også muligheden for et stort søslag mellem de to flåder, hvor man tilmed risikerede tysk overlegenhed. Dette viser opgavens høje prioritet. Fra en tysk krigsfange havde briterne desuden fået informationer om et ammunitionsdepot seks $\mathrm{km}$ øst for Tønder, som skulle forsyne alle militære installationer i Nordslesvig med ammunition. Krigsfangen havde udført straffearbejde på MarineLuftschiff-Detachement Tondern i et halvt år. Depotet beskrives som værende 200 meter langt og fem meter højt, og burde dermed være ret fremtrædende i det flade landskab. Hvorvidt depotet rent faktisk har eksisteret eller ej, er det ikke lykkedes denne forfatter at konstatere. Men briterne troede på det, hvilket gav endnu en god grund til at 
gennemføre angrebet. Det samme gjorde krigsudviklingen i det hele taget: Rusland var i mellemtiden trådt ud af krigen, mens USA til gengæld var trådt ind. Tyskland havde gennemført en række forgæves offensiver på vestfronten i sommeren 1918, og den allierede modoffensiv satte ind netop den 18. juli 1918.

\section{Konklusion}

Marine-Luftschiff-Detachement Tondern havde stor krigsmæssig betydning, både for den kejserlige tyske marine og for hele søkrigsforløbet. Basens hovedopgave var rekognoscering, og basen var tiltænkt og kom også til at udføre netop denne meget vigtige opgave i kampen mod den engelske flåde. Det var hensigten med den tyske militære ledelses luftskibsstrategi og -taktik at udligne den engelske overlegenhed med hensyn til flådefartøjer. Da englænderne indførte fjernblokaden, besluttede tyskerne at anlægge en luftskibsbase i Tønder efter en nøje kalkuleret militær vurdering.

Hverken basen i Tønder og andre luftskibsbaser fik nogen betydning for selve Jyllandsslaget. Ingen af dem kunne forud for eller under slaget levere en effektiv rekognoscering. Men det betød ikke, at basernes evne til at levere rekognoscering eller at udligne Grand Fleets numeriske overtal blev draget $\mathrm{i}$ tvivl, og både de tyske og engelske militære ledere bibeholdt overbevisningen om, at baserne og luftskibene var af vital betydning for den kejserlige tyske marine.

Marine-Luftschiff-Detachement Tonderns krigsmæssige betydning efter Jyllandsslaget var derfor ekstra stor, eftersom basen fløj $46 \%$ af alle efterfølgende rekognosceringsmissioner i 1916 for dermed at bidrage til at opretholde balancen mellem den engelske og den tyske flåde. Samtidig må man konkludere, at basen i Tønder sandsynligvis var hovedårsagen til, at der ikke kom et afgørende - og formentlig krigsforandrende - angreb fra Grand Fleet.

Angrebsflyvningen udgjorde kun $6 \%$ af basen i Tønders operative opgaver og må dermed betegnes som mindre betydningsfuld. På trods af basens lille andel i angrebsflyvningerne, var de dog også af stor betydning for den kejserlige marine. Basen bidrog til at opretholde presset på den engelske infrastruktur og var med til at tvinge briterne til at holde en stor del af sit militær hjemme. Dermed fik angrebsflyvningerne betydning for den samlede krigsindsats.

Årsagerne til angrebet på basen 19. juli 1918 var Marine-Luftschiff- 


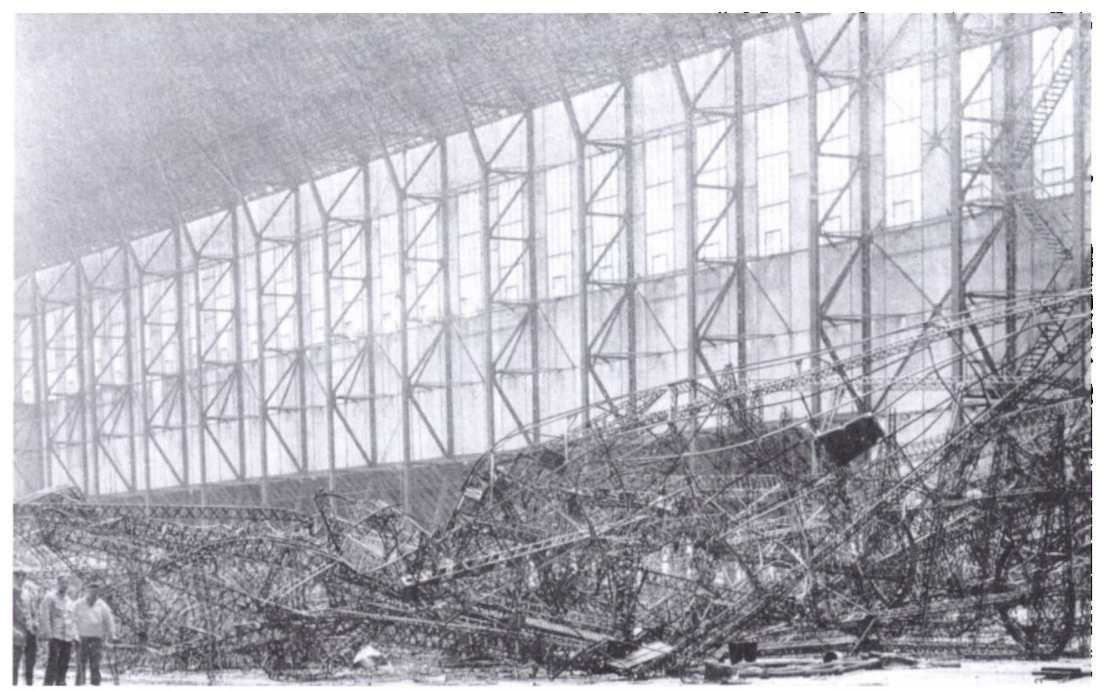

Resterne af luftskibene $L 54$ og L60 syner ikke af meget $i$ hangaren "Toska ". "Toska" var 242 meter lang, 73 meter bred og 42 meter høj og dermed langt den største og højeste bygning $i$ hele det vestlige Sønderjylland. Foto: Zeppelin-Museet, Tønder.

Detachement Tonderns betydningsfulde deltagelse i rekognoscering, basens betydning for opretholdelsen af status quo mellem flåderne efter Jyllandsslaget samt deltagelse $\mathrm{i}$ angrebsflyvningen. Men årsagerne og de strategiske overvejelser skal ses i et større perspektiv, hvor andre faktorer også har påvirket beslutningen om at angribe basen i Tønder: Englændernes vedvarende onske om at udslette luftskibene ved baserne, den efter engelsk opfattelse forøgede trussel efter angrebet 19. oktober 1917, efterretningsrapporten om hovedammunitionsdepotet øst for Tønder samt udviklingen af krigen på Vestfronten 1918 og modoffensivens start den 18. juli 1918.

\section{LITTERATUR OG KILDER}

Utrykte kilder

Bundesarchiv-Militärarchio Freiburg $M F)$ :

RMa116/77. 2.1.1915-31.7.1918. Kriegstagebuch/Luftschiff-Detachement Tondern.

RM 112/22. 1.1.1918-31.10.1918. Kriegstagebuch/Hallenschutzstation Tondern.
Foreligger i kopi på Zeppelin-museet i Tønder.

National Archives (NA):

Air $1 / 344 / 15 / 226 / 287$. Attack on the Zeppelin sheds in Tondern.

Air 1/455/15/312/44. Reports and notes on bombing of Tondern 1918. 
Air $1 / 639 / 17 / 122 / 190$. Intelligence summary of Tondern and district. July 1918.

Foreligger $\mathrm{i}$ kopi på Zeppelin-museet $\mathrm{i}$ Tønder.

\section{Litteratur}

Becker, Hans-Jürgen: 100 Jahre Luftschiff. Stuttgart, 2000.

Christiansen, W.: Luftangrebet på Tønderbasen 19-7-1918, Sønderjysk Mănedsskrift, 1964, s. 201-13.

Churchill, Winston: The World Crisis 1918-1928. New York, 1929.

Gilbert, Martin: Winston Churchill. Kobenhavn, 2005.

Grainger, John D.: The Maritime Blockade of Germany in the Great War: The Northern Patrol 1914-1918. Ashgate, 2003.

Guillaume, De Syoni: Zeppelin, Germany and the Airship. London, 1966.

Jones, H.A.: The War in the Air. London, 1969.
Kleinheins, Peter: Die Grossen Zeppeliner. Berlin-Heidelberg, 2005.

Knäusel, Hans G.: Mythos Zeppelin. Oberhaching, 2003.

Koop, Burkhard: Interneret i Danmark under første verdenskrig. Münster, 2005.

Lidegaard, Bo: Overleveren. København, 2004.

Marckmann, Anton: Ofrene fra den store krig 1914-1918. Aabenraa, 2005.

Powers, Barry D.: Strategy without Slide-rule. London, 1976.

Robinson, Douglas H.: The Zeppelin in Combat. 1994.

Schmalenbach, Paul: Die Deutschen Marine-Luftschiffe. 1977.

Stegemann, Bernd: Die deutsche Marinepolitik 1916-1918. Berlin, 1970.

Tarrant, V.E.: Jutland, the German Perspective. London, 1995.

Willmott, H.P.: First World War. London, 2004.

\section{NOTER}

1. Robinson, 1994, s. 339.

2. Stegemann, 1970 , s. 17. Tarrant, 1995, s. 21.

3. Willmott, 2004, s. 172.

4. Stegemann, 1970 , s. 18 .

5. Tarrant, 1995, s. 21-23.

6. Grainger, 2003 , s. 1-5.

7. Tarrant, 1995 , s. 22 , s. 27.

8. Robinson, 1994 , s. 54.

9. Schmalenbach, 1977 , s. 88 og s. 58 .

10. Jones, 1969 , s. 357.

11. Schmalenbach, 1977 , s. 30.

12. Ibid, s. 87-88. Robinson, 1994, s. 33.

13. Robinson, 1994 , s. 31 .

14. Robinson, 1994 , s. 398. Det samlede antal marineluftskibe afviger; Becker nævner 73, Robinson 74, Schmalenbach 76. Robinson, 1994, s. 395.

15. Tarrant, 1995, s. 253.

16. B-MF, Kriegstagebuch. Resultaterne er beregnet ved en gennemgang af krigsdagbogerne.

17. Tarrant, 1995 , s. 46 .

18. Ibid, s. 49. Robinson, 1994, s. 156.
19. Tarrant, 1995, s. 50.

20. B-MF, Kriegstagebuch. Det fremgår dog af dagbøgerne, at luftskibene $L 24$ og $L 22$ rekognoscerer.

21. Tarrant, 1995 , s. 54 .

22. Robinson, 1994, s. 163.

23. Willmott, 2004, s. 180.

24. Howard, 2002, s. 85.

25. Robinson, 1994, s. 164-165.

26. Tarrant, 1995, s. 77.

27. Schmalenbach, 1977, s. 110.

28. B-MF, Kriegstagebuch.

29. Robinson, 1994 , s. 169.

30. Tarrant, 1995 , s. 249.

31. Kleinheins, 2005 , s. 148 .

32. NA, Air 1/639/17/122/190. Intelligence Summary of Tondern and District. July 1918.

33. Robinson, 1994, s. 398.

34. Robinson, 1994, s. 398. B-MF, Kriegstagebuch. Resultaterne er beregnet ved en sammenligning af krigsdagbøgerne og de hos Robinson beregnede resultater.

35. Becker, 2000 , s. 61 . 
36. Robinson, 1994, s. 78-79. Det dokumenteres yderligere i det tyske admiralstabsværk: Der Krieg zur See 1914-1918, Abtheilung I: Nordsee, bd. 1-6 og lader dermed ikke nogen tvivl tilbage om hovedårsagen.

37. Becker, 2000, s. 66.

38. Powers, 1976, s. 13.

39. Schmalenbach, 1977, s. 123.

40. Becker, 2000, s. 69.

41. Powers, 1976, s. 15.

42. Schmalenbach, 1977 , s. 160.

43. Powers, 1976 , s. 33, s. 18.

44. Schmalenbach, 1977, s. 160 . Robinson, 1994 , s. 229 f, s. 342.

45. Becker, 2000 , s. 64 .

46. Kleinheins, 2005, s. 147.

47. Becker, 2000, s. 64 .
48. Robinson, 1994, s. 231.

49. Kleinheins, 2005 , s. 147 .

50. Robinson, 1994, s. 230-234.

51. Schmalenbach, 1977, s. 123.

52. Robinson, 1994, s. 253.

53. B-MF, Kriegstagebuch. Robinson, 1994, s. 287.

54. Kleinheins, 2005, s. 147.

55. Robinson, 1994, s. 302-304.

56. Ibid, s. 16.

57. Jones, 1969, vol. I, s. 389-402.

58. B-MF, Kriegstagebuch.

59. NA, Air $1 / 344 / 15 / 226 / 287$. Attack on the Zeppelin Sheds in Tondern. Air 1/455/15/312/44. Reports and Notes on Bombing of Tondern 1918. Tarrant, 1995, s. 255263. 